\title{
GMR
}

\section{Morphology and muscle gene expression in GIFT and Supreme Nile tilapia varieties reared in two cultivation systems}

\author{
E.C.S. Lima ${ }^{1}$, J.A. Povh ${ }^{2}$, R.A.A. Otonel ${ }^{3}$, J.H. Leonhardt ${ }^{4}$, A.A. Alfieri ${ }^{3}$, \\ S.A. Headley ${ }^{3}$, F.P. Souza ${ }^{1}$, A.R. Poveda-Parra ${ }^{1}$, P.J. Furlan-Murari ${ }^{1}$ and \\ N.M. Lopera-Barrero ${ }^{1}$ \\ ${ }^{1}$ Departamento de Zootecnia, Programa de Pós-Graduação em Ciência Animal, \\ Universidade Estadual de Londrina,Londrina, PR, Brasil \\ ${ }^{2}$ Faculdade de Medicina Veterinária e Zootecnia, \\ Universidade Federal de Mato Grosso do Sul, Campo Grande, MS, Brasil \\ ${ }^{3}$ Departamento de Medicina Veterinária Preventiva, \\ Programa de Pós-Graduação em Ciência Animal, \\ Universidade Estadual de Londrina, Londrina, PR, Brasil \\ ${ }^{4}$ Departamento de Ciências Fisiológicas, Universidade Estadual de Londrina, \\ Londrina, PR, Brasil \\ Corresponding author: N.M. Lopera-Barrero \\ E-mail: nmlopera@uel.br
}

Genet. Mol. Res. 16 (1): gmr16019407

Received October 5, 2016

Accepted December 19, 2016

Published March 16, 2017

DOI http://dx.doi.org/10.4238/gmr16019407

Copyright (C) 2017 The Authors. This is an open-access article distributed under the terms of the Creative Commons Attribution ShareAlike (CC BY-SA) 4.0 License.

\begin{abstract}
Tissue growth in most fishes occurs by muscular hyperplasia and hypertrophy, which are influenced by different regulatory factors, such as myostatin. The current study evaluated the influence of cultivation in hapas and earthen ponds on the diameter of white muscle fibers and on the myostatin (MSTN-1) gene in GIFT and Supreme varieties of tilapia. Fish of both varieties were reared for 204 days and then divided into four developmental stages. White muscle samples, corresponding to 100 fibers per slide, were collected from the middle region of fish of each variety and cultivation system, and
\end{abstract}

Genetics and Molecular Research 16 (1): gmr16019407 
were measured and divided into two classes representing hyperplasia and hypertrophy. Samples were subjected to real-time PCR to analyze gene expression. Hyperplasia decreased during the developing stages, coupled with increased hypertrophy. There was a higher rate of hypertrophy in fish raised in earthen ponds when compared to those raised in hapas, during juvenile and developing phases, and greater hypertrophic growth was observed in GIFT specimens when compared to Supreme specimens in earthen ponds. Since increased MSTN-1 gene expression was observed in GIFT specimens during the developing phase in pond cultivations, and in Supreme tilapia in hapas, MSTN-1 expression is related to greater hypertrophy. These results demonstrate the capacity for increased muscle growth in earthen pond cultivation in which the GIFT variety developed best. How the environment affects the growth of different tilapia varieties may be employed to optimize culture management and genetic improvement programs. Further investigations should aim to describe mechanisms affecting muscle growth and development.

Key words: Fish farming; GIFT; Muscle morphometry; MSTN-1; Oreochromis niloticus; Tilapia

\section{INTRODUCTION}

Nile tilapia (Oreochromis niloticus) is one of the most cultivated fish species produced worldwide (FAO - Food and Agriculture Organization of the United Nations, 2014). In 2011, Brazil had the highest production rates of Nile Tilapia among all species, with a production of 253,824 tons (MPA - Ministério da Pesca e Aquicultura, 2013). Nile tilapia is an omnivorous filter feeder that reproduces easily. It also adapts to a variety of cultivation systems and produces white, good quality flesh (Rodriguez Rodriguez, 2014).

An important aspect of tilapia and other cultivated fish species is the growth of striated skeletal muscle, since the tissue constitutes $40-75 \%$ of the total body mass (Carani et al., 2008). Among the different muscle types, white tissue represents more than $90 \%$ of the muscle tissue in most teleost fish, and, therefore, changes in body mass mainly occur due to changes in the growth of this muscle (Alami-Durante et al., 2010a). Post-embryonic muscle growth in fishes involves precursor cells, such as undifferentiated myoblasts or myosatellite cells (Johnston, 1999). According to Johnston et al. (2011), differentiating myosatellite cells intercalate in pre-existing muscle fibers, increasing their length and diameter, or else, they participate in the formation of myotubes.

In most fish, muscle growth is indeterminate and occurs via hyperplasia and hypertrophy (Rodriguez Rodriguez, 2014). Hyperplasia is induced by the recruitment of new muscle fibers and hypertrophy is mediated by the growth of existing fibers (Alami-Durante et al., 2010b). Changes in the relative contribution of these processes alter the size distribution of muscle fibers (Alami-Durante et al., 2010a). These changes are of great importance since, from a productive point of view, variations in the diameter and number of fibers is influenced by genetic and environmental factors (Johnston, 1999). In this context, differences in the distribution pattern of muscle fiber size have been reported between different species

Genetics and Molecular Research 16 (1): gmr16019407 
(Valente et al., 1999; Periago et al., 2005), and in response to environmental factors, including temperature (Stoiber et al., 2002; Gutierrez de Paula et al., 2014), oxygen levels (Matschak et al., 1998), and diet composition (Alami-Durante et al., 2010a,b). Developmental phase also affects the size of the fibers with smaller diameter fibers more frequently found in early fish stages and larger diameter fibers in adult Tilapia (Dal Pai-Silva et al., 2003; Aguiar et al., 2008; de Almeida et al., 2008).

Another important aspect is regulation by growth factors, particularly myostatin, which belongs to the transforming growth factor $\beta$ (TGF- $\beta$ ) superfamily, including factors that negatively regulate muscle growth (Seiliez et al., 2012). The likely role of myostatin in the development of striated skeletal muscle in fish is to control the proliferation (Seiliez et al., 2012) and differentiation (Langley et al., 2002) of myogenic precursor cells. In teleosts, unlike mammals, myostatin is not transcribed by a single gene, and at least two paralogs exist: MSTN-1 and MSTN-2 (de Santis et al., 2012).

Suppression of myostatin activity has been evaluated in some species of fishes, and studies have shown that its ability to inhibit growth and increase muscle mass is primarily through hyperplasia, hypertrophy, or both (Xu et al., 2003; Acosta et al., 2005; Lee et al., 2009; Chisada et al., 2011). This justifies interest in this factor from a production point of view. The myostatin gene is regulated by intrinsic, environmental, and other factors, according to developmental phase, temperature, and dietary restrictions (Xu et al., 2003; Weber and Bosworth, 2005; Nebo et al., 2013). In fact, environmental factors may alter the expression of certain genes (Zhao et al., 2015). Those authors reported that high alkalinity stress in tilapias modulated the expression of several genes related to adaptability and tolerance to this condition. It is possible that factors present in the cultivation environment affect myostatin gene expression in an attempt to regulate muscle growth.

As described, muscle growth can be influenced by genetic factors, developmental phase of the fish, and environmental conditions. Environmental conditions vary according to the cultivation system employed. Concrete tanks and earthen ponds are employed for tilapia culture. Earthen ponds are more advantageous than concrete tanks due to the greater availability of natural feed, which may positively affect performance and other production characteristics (Ribeiro et al., 2011; Abou et al., 2013). This may be related to increased muscle growth and to several other factors related to growth, such as myostatin. Therefore, it is important to understand the impact of these factors in order to improve the productive performance of $O$. niloticus varieties. Thus, the aim of the present study was to evaluate the effect of hapas in concrete tanks and earthen ponds on the distribution of white muscle fiber diameter and the expression of the myostatin gene in the GIFT and Supreme varieties.

\section{MATERIAL AND METHODS}

\section{Study site and experimental conditions}

The experiments were conducted at two different sites. Cultivations in hapas were carried out in the city of Londrina and cultivations in earthen ponds in the municipality of Florestópolis, both of which are located in the northern region of the State of Paraná. Sexreversed Nile tilapia GIFT fingerlings (5th generation improved by the State University of Maringa, Parana, Brazil) and Supreme varieties with an initial average weight of $0.83 \mathrm{~g}$ and an average length of $2-3 \mathrm{~cm}$ were used in the study. Initially, 200 fingerlings of each variety were

Genetics and Molecular Research 16 (1): gmr16019407 
cultivated in hapas (400 in total) and 1234 in earthen ponds (2468 in total). The experimental period lasted 204 days starting on January 29, 2013 and ending on August 20, 2013 and was divided into fingerling, juvenile, growing, and fattening stages.

In the hapa cultivations, fish were placed in net cages made from 1 × 2 -mm green shading mesh that was $1.4-\mathrm{m}$ long $\times 0.6-\mathrm{m}$ wide $\times 0.8-\mathrm{m}$ deep. One hapa per variety was used. The hapas were located in the same concrete tank with constant water input and output (complete renewal every $290 \mathrm{~min}$ ) from an artesian well. In this system, reclassification handling was performed at the end of each developing phase. The purpose of this procedure was to maintain uniformity between plots based on average weights. Because of this, the number of fish at the beginning of each cultivation stage was different and included 143 juveniles of both varieties, 108 growth stage individuals of both varieties, and 40 GIFT and 60 Supreme fattening stage individuals. At the beginning of the fattening stage due to their larger size, GIFT fish were transferred to three hapas and the Supreme to four (due to the different number of individuals between varieties). All hapas were placed in the same concrete tank.

In the earthen pond cultivation systems, fish were allocated to nurseries of $200 \mathrm{~m}^{2}(10$ $\times 20 \mathrm{~m}$ ), which were supplied with mineral water. A nursery was used for each variety, and fish remained in the nurseries until the end of the experimental period. A single reclassification was performed at the end of the juvenile stage (due to the increased difficulty implementing this system) and 600 fish of each variety were maintained until the end of the experiment.

In both systems, the same feeding methods and specific portions were used for each phase, namely fingerling, juvenile, growth, and fattening, consisting of meal with $55 \%$ crude protein $(\mathrm{CP}), 1.0-\mathrm{mm}$ pellets with $45 \% \mathrm{CP}, 1.7-\mathrm{mm}$ pellets with $42 \% \mathrm{CP}$, and $3.0-\mathrm{mm}$ pellets with $30 \% \mathrm{CP}$, respectively. The feed was provided ad libitum throughout the experimental period, and the amount administered was divided into three daily rations.

The following water quality parameters were analyzed weekly in both farming systems: temperature $\left({ }^{\circ} \mathrm{C}\right), \mathrm{pH}$, dissolved oxygen $(\mathrm{DO} ; \mathrm{mg} / \mathrm{L})$, alkalinity $(\mathrm{mg} / \mathrm{L})$, toxic ammonia $(\mathrm{mg} / \mathrm{L})$, and turbidity with a Secchi disk $(\mathrm{cm})$.

This study was approved by the Ethics Committee on Animal Use of the State University of Londrina (registration process No. 10375.2013.64).

\section{White muscle morphology}

Samples were collected for histological analysis on days 23, 50, 113, and 204 after the beginning of the experiment, representing the final days of the fingerling, juvenile, growing, and fattening stages, respectively. Five fish of each variety were randomly collected from each stage from each cultivation system (20 individuals from each stage) and transported to the laboratory at the Aquaculture Station at the State University of Londrina (EPUEL) where they remained for about $24 \mathrm{~h}$. The fish were then anesthetized with $5 \mathrm{~mL}$ eugenol (clove oil) diluted in $1 \mathrm{~L}$ water and euthanized by decapitation. A sample of white muscle was collected from the middle portion of the body below the dorsal fin of each specimen, fixed in buffered formalin $(10 \%)$, preserved in $70 \%$ alcohol, and then embedded in paraffin.

Of these samples, $5 \mu \mathrm{m}$ cross-sectional cuts were made, stained with hematoxylin and eosin (HE), and mounted to display one fish per histology slide. On each slide, the area corresponding to 100 white muscle fibers was measured with the use of an optical microscope connected to a Motic Images Advanced 3.2 (Motic ${ }^{\circledR}$ Leica microscope, USA) image analyzer program. The values obtained were applied to the formula $\mathrm{D}=2 \mathrm{~A}^{0.5} \pi^{-0.5}$ as proposed by Valente

Genetics and Molecular Research 16 (1): gmr16019407 
et al. (1999) to indirectly calculate fiber diameter (D), where A is the fiber area. Diameters were grouped into four classes: $<20 \mu \mathrm{m}, 20-30 \mu \mathrm{m}, 30-50 \mu \mathrm{m}$, and $>50 \mu \mathrm{m}$. The first two classes relate to hyperplastic growth and the latter two to hypertrophic growth (Rodriguez-Rodriguez, 2014). To evaluate the relative contribution of hyperplastic and hypertrophic mechanisms, the areas were expressed as the frequency (\%) of fibers in each class, and the averages for each variety in each system were calculated. The data for each class were evaluated during different stages of cultivation using a Kruskal-Wallis one-way ANOVA. A Student's $t$-test was applied to assess the differences between varieties in each system and between systems within each variety, both with a significance level of 5\% (Salomão, 2014). All analyses were performed using the statistical program $\mathrm{R}$ version 3.1.3. Data are presented in bar graphs, with means and standard deviations for the percentage of fibers in each class diameter, for each variety, for each system, for each cultivation phase.

\section{Myostatin gene expression}

To quantitatively evaluate myostatin expression, reverse transcription was performed, and this was followed by real-time polymerase chain reaction (RT-PCR). Expression was evaluated for the growing and fattening stages. Three samples were collected for each stage, system (hapas and earthen ponds), and variety combination. After collection, the samples were placed in individual tubes containing RNAlater ${ }^{\circledR}$ solution $\left(\right.$ Ambion $^{\circledR}$, Life Technologies ${ }^{\mathrm{TM}}$, USA) and maintained refrigerated until analysis.

RNA extraction was performed from 50-mg muscle samples using the reagent TRIzol ${ }^{\mathbb{B}}$ (Ambion $^{\circledR}$, Life Technologies ${ }^{\mathrm{TM}}$, USA) according to the product manual. The total amount of RNA obtained was quantified with a spectrophotometer. Next, the samples were treated with DNase using a DNAse I Amplification Grade kit (Invitrogen ${ }^{\mathrm{TM}}$, Life Technologies ${ }^{\mathrm{TM}}$, USA) following the instructions of the manufacturer.

To quantitatively evaluate myostatin expression, reverse transcription followed by RT-PCR were performed using primers for myostatin, the MSTN-1 paralog, and beta-actin $(\beta \mathrm{ACT})$ as a housekeeping gene (Table 1). For this, a GoTaq ${ }^{\circledR}$ 1-Step RT-PCR System kit (Promega, USA) was used according to the technical kit manual. Reactions for each gene were carried out in duplicate using a Real-Time PCR System 7500 (Applied Biosystems ${ }^{\circledR}$, USA) for one cycle at $37^{\circ} \mathrm{C}$ for $15 \mathrm{~min}$. This was followed by a cycle of $95^{\circ} \mathrm{C}$ at $10 \mathrm{~min}$ conducted to inactivate the reverse transcription reaction and activate the real-time PCR for 40 cycles of denaturation at $95^{\circ} \mathrm{C}$ for $10 \mathrm{~s}$, annealing at $60^{\circ} \mathrm{C}$ for $30 \mathrm{~s}$, and extension at $72^{\circ} \mathrm{C}$ for $30 \mathrm{~s}$. Finally, a dissociation cycle was performed at a temperature of $60^{\circ}-95^{\circ} \mathrm{C}$.

Table 1. Characterization of the genes used for Myostatin gene expression.
\begin{tabular}{|l|l|c|c}
\hline Gene & Primer sequence & Amplification size (bp) & Genbank accession No. \\
\hline MSTN 1 & 5'--GCAACCACGGAGACAATT-3' & 58 & FJ972683 \\
\hline BACT & 5'-CACCTGGACAGCGGAATCA-3' & 52 & EU887951 \\
\hline & 5'-ACCTTCAACACCCCCGCCAT-3' & & \\
\hline
\end{tabular}

Adapted from Mareco (2012).

For each of the genes studied, standard dilution curves were constructed using serially diluted cDNA (with a pool of randomly selected samples) to calculate the amplification efficiency. Results of amplification reactions were used to produce graphs of $\mathrm{Ct}$ values versus

Genetics and Molecular Research 16 (1): gmr16019407 
$\log 10$ of the number relative to the dilution copies in series. A linear regression was performed to determine the angular coefficient of the slope used to calculate amplification efficiency with Equation 1 by Rasmussen (2001):

$$
\text { Efficiency }=[10(-1 / \text { angular coefficient of slope })] \quad(\text { Equation } 1)
$$

The relative expression (R) of the target gene was based on amplification efficiency (E) and the PCR cycle for the treatment and control group. An increase in fluorescence was detected above the baseline signal (Ct) (Pfaffl, 2001). The method described by Pfaffl (2001) was used for relative quantification, and the relative expression was determined with Equation (2)

$$
\text { Relative expression }(\mathrm{R})=\frac{\mathrm{E} \text { target gene }}{\mathrm{E} \text { control target gene Treatment }-\mathrm{Ct} \text { target gene Control) }} \text { (Eq control gene Treatment - Ct control gene Control) }_{\text {Equation 2) }}
$$

where $\mathrm{E}=$ efficiency of primer amplification; $\mathrm{Ct}$ (threshold cycle) $=$ PCR cycle in which fluorescence was detected above the baseline signal of the equipment.

An ANOVA was performed using the gene expression data with the statistical program $\mathrm{R}$, and a significance level of 5\% was adopted. Data are presented in bar graphs, with means and standard deviations for myostatin for each variety, for each cultivation system, within the growth and fattening phases.

\section{RESULTS}

\section{Water quality parameters}

When analyzing water quality parameters, differences in temperature and DO levels were observed between the different cultivation systems (Figure 1). Parameters such as $\mathrm{pH}$, alkalinity, and toxic ammonia were found to be within the recommended levels (Kubitza, 2011; Moro et al., 2013). During the experimental period, the $\mathrm{pH}$ ranged between 6.2 and 6.4 in hapas, between 7.0 and 7.6 in the GIFT pond, and between 7.2 and 7.6 in the Supreme pond. Alkalinity $(\mathrm{mg} / \mathrm{L})$ ranged between 30 and $35 \mathrm{mg} / \mathrm{L}$ in hapas, between 25 and $30 \mathrm{mg} / \mathrm{L}$ in the GIFT pond, with $30 \mathrm{mg} / \mathrm{L}$ in all the cultivation phases of the Supreme pond. Toxic ammonia $(\mathrm{mg} / \mathrm{L})$ was zero in the two varieties in the two systems and in all cultivation phases. The optimal temperature range for tilapia cultivation varies between 26 and $30^{\circ} \mathrm{C}$ (Kubtiza, 2011). During all stages of cultivation in the hapas, the temperature was below these values because the water was from an artesian well, and maintained its underground temperature without many fluctuations during the trial period. In cultivations carried out in the earthen ponds, low temperatures were observed only during the last phase. As for DO, the minimum level required for growing tilapia is $3 \mathrm{mg} / \mathrm{L}$ (Moro et al., 2013). In the hapas, the values were below or near these levels throughout the experimental period, and in earthen ponds, the levels were higher than the minimum required in all phases for both varieties. Moreover, differences in turbidity (Figure 1) ranged between 40 and 80 in the GIFT variety ponds and between 40 and $60 \mathrm{~cm}$ in the Supreme variety ponds, with $100 \%$ in hapas at all phases (data not shown in Figure 1 since they are not numerical variables). These results demonstrate the effect of natural food and show there is an absence or low availability of this type of food in the hapas.

Genetics and Molecular Research 16 (1): gmr16019407 

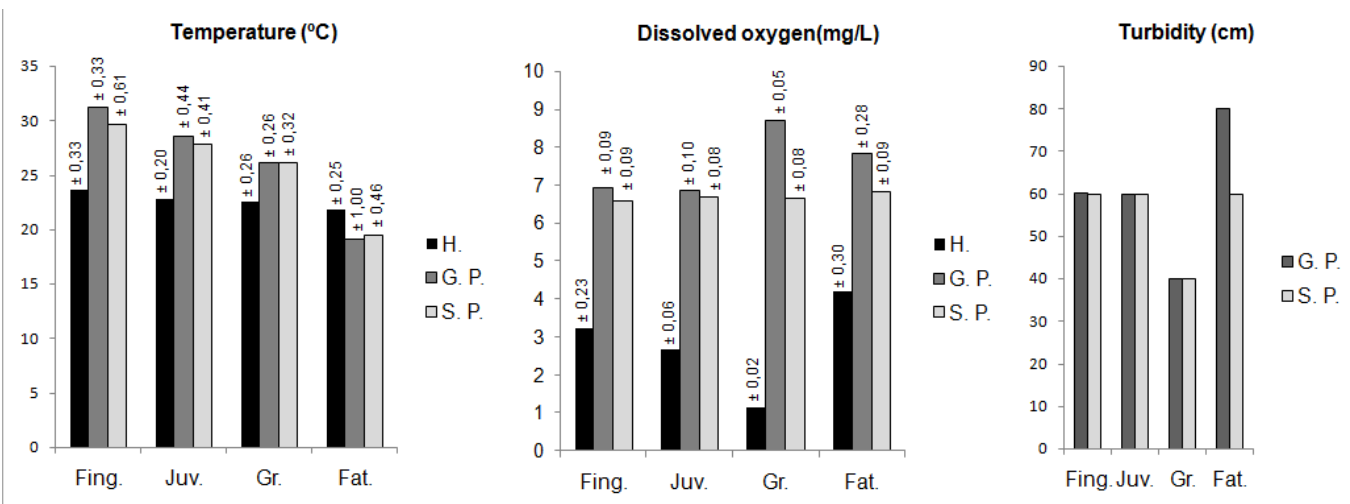

Figure 1. Temperature and dissolved oxygen during each phase in each cultivation system and transparency in ponds during each phase with means plus standard deviations. Fing: fingerlings, Juv: juvenile, Gr: growing, Fat: fattening, H: hapas of both varieties, GP: GIFT earthen ponds, SP: Supreme earthen ponds.

\section{Distribution of white muscle fiber diameter}

Regarding the distribution of muscle fiber diameters (means plus standard deviations), differences between varieties and systems were observed throughout the stages. In the fingerling stage (Figure 2), fibers with a diameter $<30 \mu \mathrm{m}$ prevailed in all system and variety combinations. However, comparison of fiber frequencies in each diameter class showed no significant differences between the system and variety combinations.

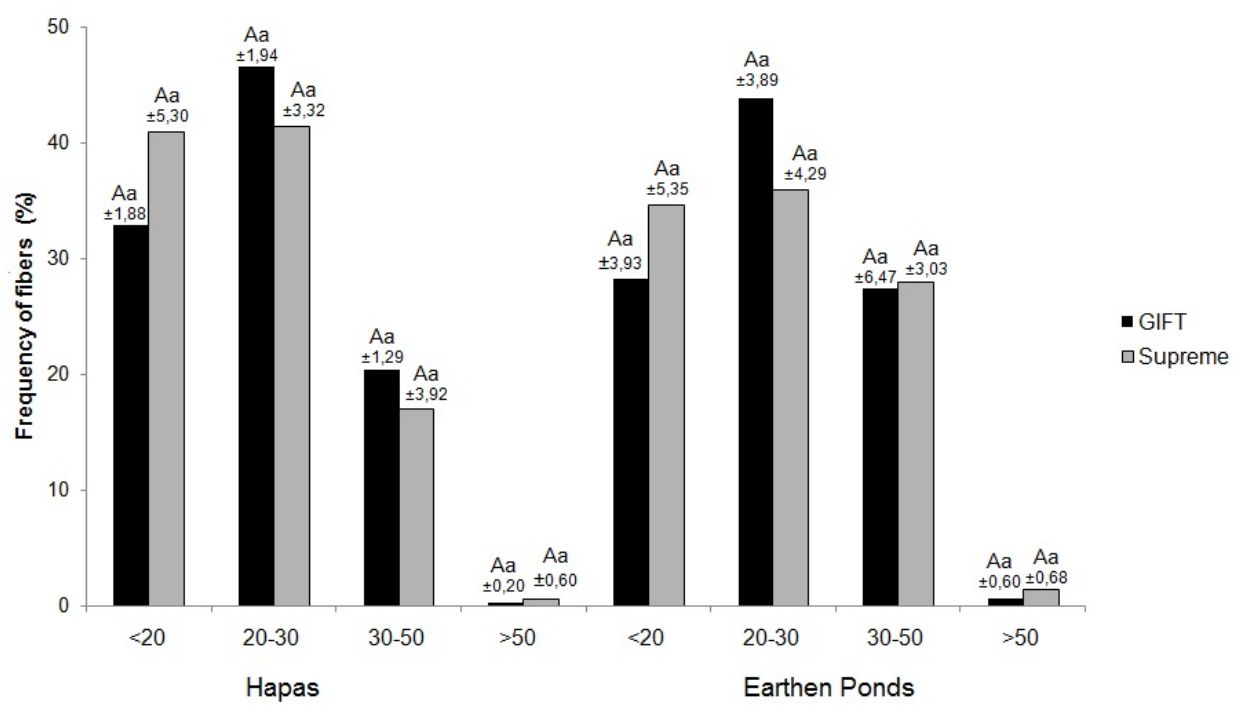

Figure 2. Frequency of diameter $(\mu \mathrm{m})$ classes of white muscle fibers during the fingerling stage, followed by means and standard deviations. Uppercase letters compare cultivation systems in the same variety and class. Lowercase letters compare varieties in the same system and class. The same upper- or lowercase letters indicate no statistical difference $(\mathrm{P}<0.05)$.

Genetics and Molecular Research 16 (1): gmr16019407 
In the juvenile stage (Figure 3), a prevalence of fish with fibers diameters $<30 \mu \mathrm{m}$ was observed in the hapas. In contrast, the prevalence of fibers in fish in the earthen ponds had diameters $>30 \mu \mathrm{m}$. In the $<20 \mu \mathrm{m}$ class, no differences were observed. A lower frequency of GIFT variety fish with fiber diameters in the 20-30 $\mu \mathrm{m}$ class were observed in earthen ponds than in the hapas. Higher frequencies of fish of both varieties with fiber diameters in the 30 $50 \mu \mathrm{m}$ class were observed in ponds compared with the hapas, and no differences were found within the $>50 \mu \mathrm{m}$ class.

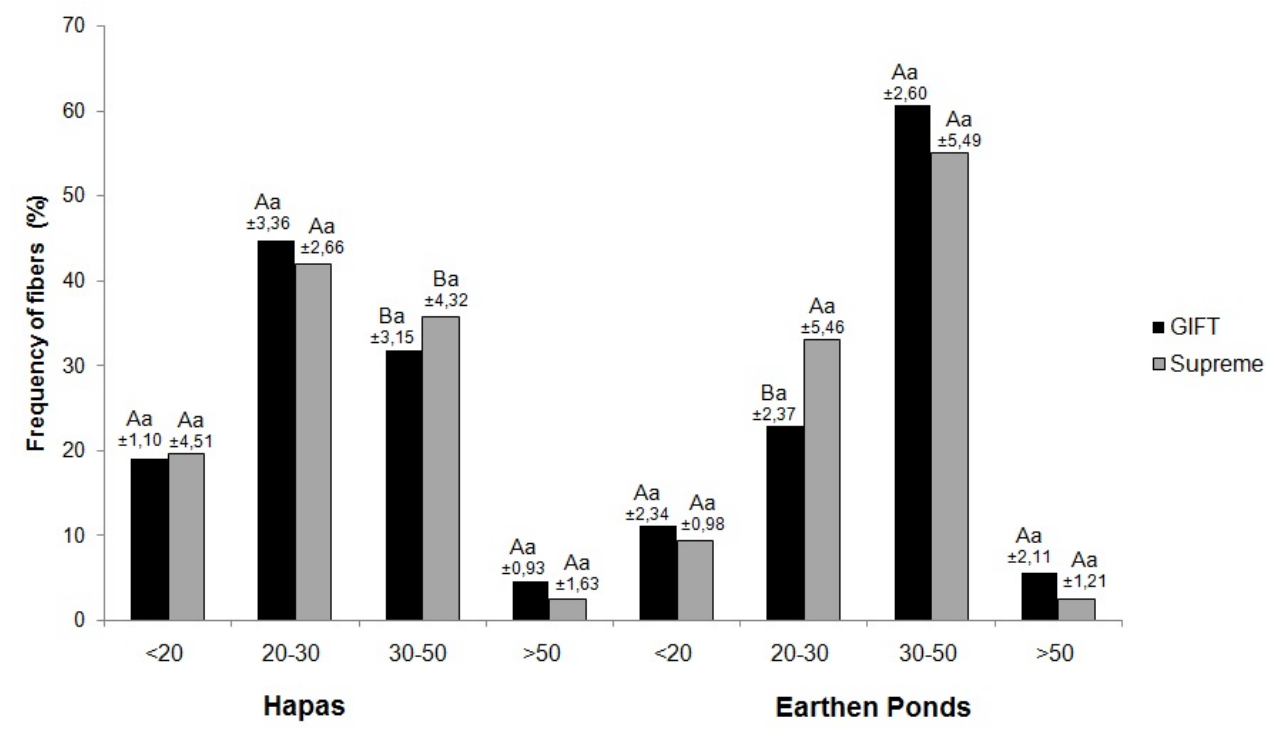

Figure 3. Frequency of fiber diameter $(\mu \mathrm{m})$ classes in the juvenile stage, with means plus standard deviation. Uppercase letters compare cultivation systems within the same variety and class. Lowercase letters compare varieties in the same system and class. Upper- or lowercase letters that are the same denote statistical significance $(\mathrm{P}<0.05)$.

During the growing phase (Figure 4), there was an increase in the number of fish with fiber diameters in the $>30 \mu \mathrm{m}$ class compared to the previous phase for all system and variety combinations. In this context, there were no differences in the $<20 \mu \mathrm{m}$ class. A higher frequency of GIFT individuals cultivated in hapas had muscle fibers with diameters of 20-30 $\mu \mathrm{m}$ compared with fish from the ponds, and they were less frequent in relation to Supreme individuals in earthen ponds. There was a lower frequency of GIFT individuals with fibers in the 30-50 $\mu \mathrm{m}$ class in ponds than in hapas; however, there was a higher frequency of GIFT individuals with fibers in the $>50 \mu \mathrm{m}$ class in ponds than in hapas. Within ponds, there was a greater proportion of GIFT individuals with fibers in the largest class compared with Supreme individuals.

During the fattening phase (Figure 5), most of the fibers exhibited diameters greater than $30 \mu \mathrm{m}$ in all variety and system combinations, with the majority being in the $>50 \mu \mathrm{m}$ diameter class. However, when assessed by size class, there were no statistical differences between the different fish varieties. 


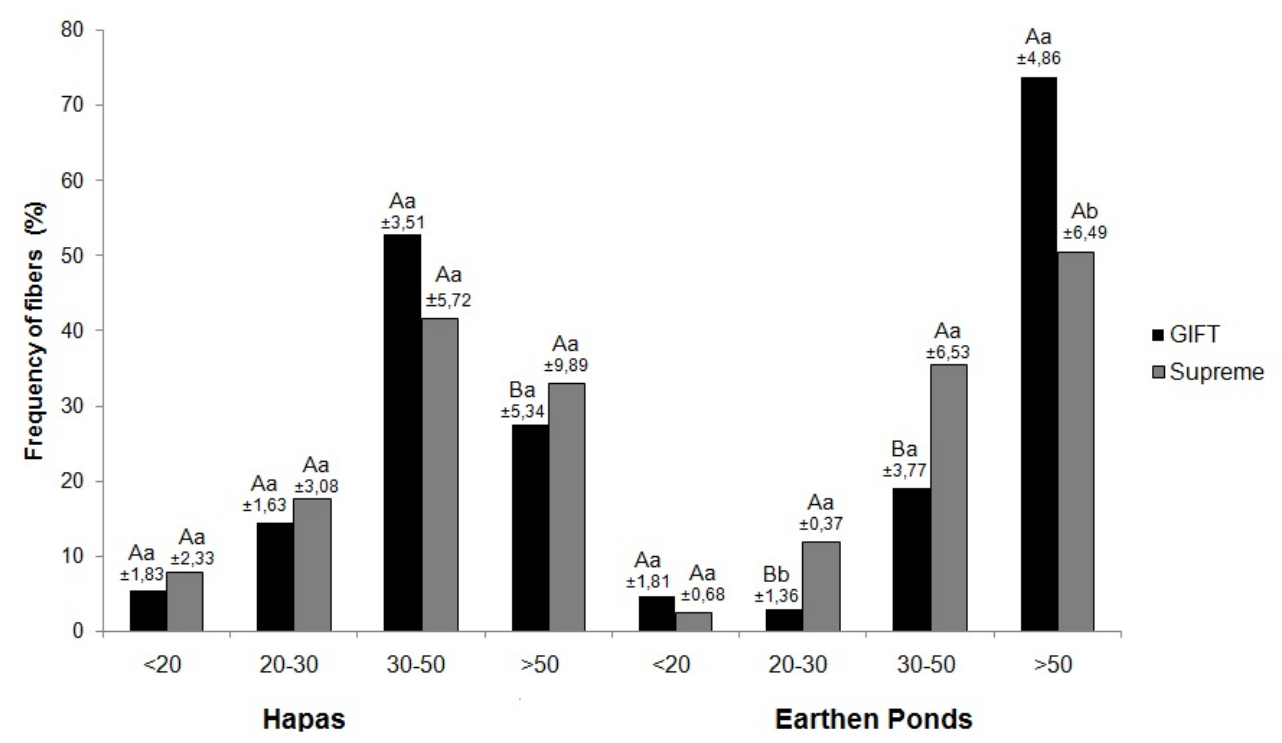

Figure 4. Frequency of fiber diameter $(\mu \mathrm{m})$ classes in the growing phase, with means plus standard deviations. Uppercase letters compare cultivation systems within the same variety and class. Lowercase letters compare varieties in the same system and class. Upper- and lowercase letters that are the same are statistically different $(\mathrm{P}<0.05)$.

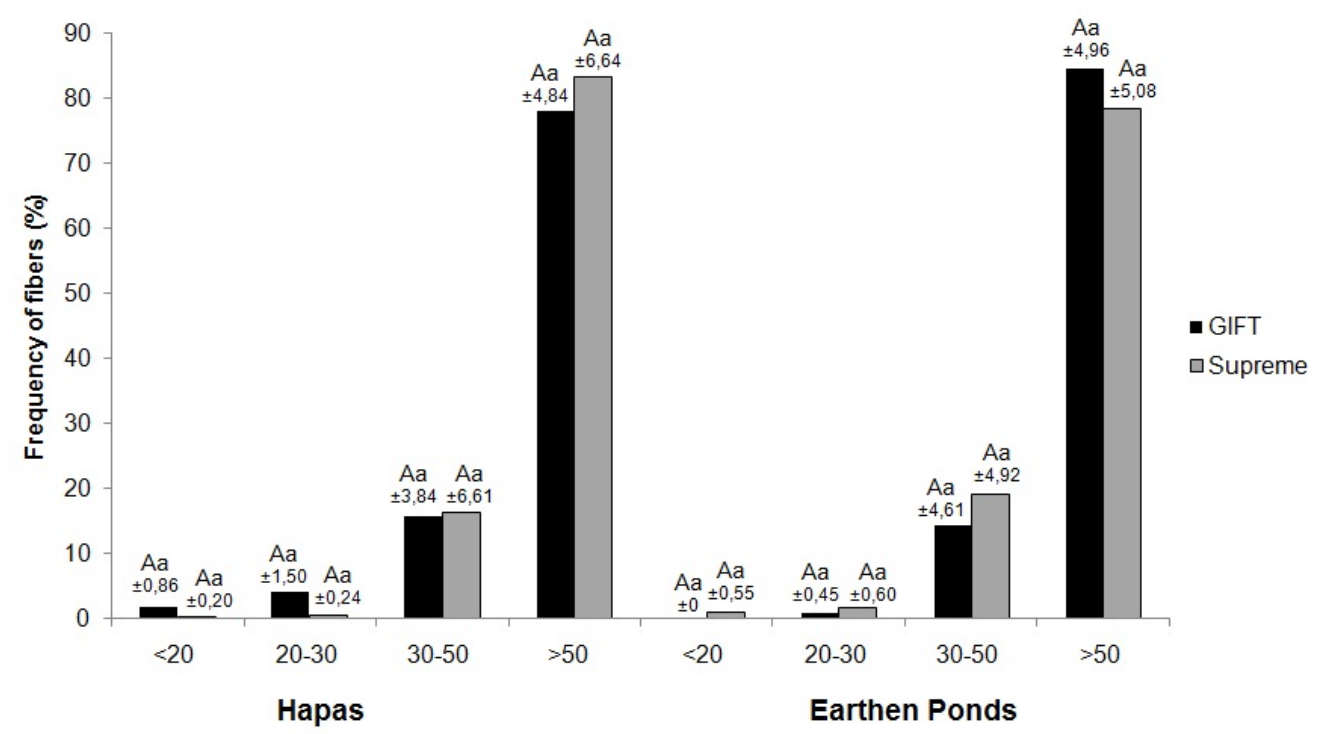

Figure 5. Frequency of white muscle fiber diameter $(\mu \mathrm{m})$ classes in the fattening phase, with means plus standard deviations. Uppercase letters compare cultivation systems within the same variety and class. Lowercase letters compare varieties in the same system and class. Upper- and lowercase letters that are the same indicate no statistical difference $(\mathrm{P}<0.05)$.

Genetics and Molecular Research 16 (1): gmr16019407 


\section{Myostatin gene expression}

Differences in the expression of myostatin were observed in the growing phase (Figure 6), with higher expression occurring in GIFT fish cultivated in earthen ponds in relation to hapas, and higher expression in Supreme fish cultivated hapas in relation to earthen ponds. There was also increased expression of myostatin in GIFT individuals in relation to Supreme individuals in cultivation ponds, and lower expression in hapas. However, this was not observed during the fattening stage. GIFT variety individuals exhibited greater expression in hapas in relation to ponds and greater in relation to Supreme variety when compared in the same system. There was no statistical difference between the two varieties in earthen ponds.

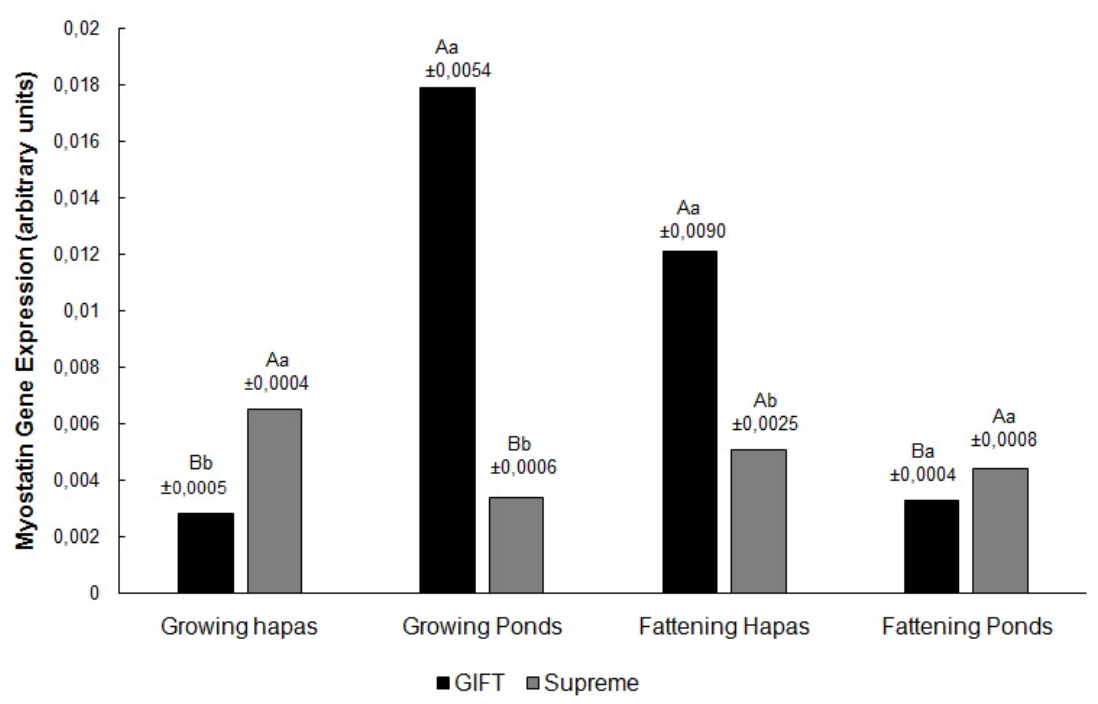

Figure 6. Gene expression of myostatin in two stages (growing and fattening), with means plus standard deviations. Uppercase letters compare cultivation systems within the same variety. Lowercase letters compare varieties within the same cultivation system.

\section{DISCUSSION}

\section{Contribution of hyperplasia and hypertrophy to muscle growth}

The gradual increase in the frequency of larger diameter fibers, and the consequent reduction of smaller diameter fibers observed over the different stages in this study confirms results obtained previously, such as those evaluating growth in Piaractus mesopotamicus (de Almeida et al., 2008), Arapaima gigas (Carani et al., 2008), and O. niloticus (Aguiar at al., 2008). Taken together with the present study, these findings indicate that although white muscle in fish grows through both hyperplastic and hypertrophic processes, it occurs in different ways with new fiber recruitment being of great importance during the early stages, and increases in fiber size are responsible for most of the growth in adulthood.

The results obtained herein demonstrate that the frequencies of fibers in the various 
size classes were only significantly different during the juvenile and developing stages. Due to the faster rate of development when compared to the fingerling and fattening stages, this may have occurred since the environmental effects of each system exerted a greater influence on the recruitment of new fibers and on the increased diameter of existing fibers. During the juvenile stage, the greatest hypertrophic growth (fibers in the 30-50 $\mu \mathrm{m}$ diameter class) occurred in both varieties in the pond cultivation systems, and this finding was complemented by the fact that the GIFT variety exhibited less hyperplasia (fibers in the 20-30 $\mu \mathrm{m}$ diameter class). During the growing phase, most hypertrophy in earthen ponds was significantly different only in the GIFT variety and was mainly evidenced by the high proportion of fibers in the $>50$ $\mu \mathrm{m}$ diameter class. Thus, the results from both stages point to greater hypertrophic growth in earthen pond cultivation.

Hypertrophy is responsible for the majority of muscle growth in fish between hatching and maturity (Johnston, 1999). When assessing muscle growth at different stages, Dal Pai Silva et al. (2003) demonstrated that hypertrophy was the main mechanism associated with increased muscle mass in the species. Thus, this study demonstrates the greatest potential for muscle growth in pond cultivations, which may be due to appropriate levels of temperature, DO, and turbidity being maintained in the system.

The effects of low temperatures on muscle growth were observed in P. mesopotamicus by Gutierrez de Paula et al. (2014), who found higher frequencies of fibers with larger diameters at 28 and $32^{\circ} \mathrm{C}$ when compared to $24^{\circ} \mathrm{C}$. Since the temperature found in the hapas throughout the experimental period in the current study was similar to the low temperatures evaluated in that study, it is possible that temperature influenced fiber growth. In the present study, low temperatures $\left(19^{\circ} \mathrm{C}\right)$ were observed in the ponds of both varieties during the fattening stage, which does not seem to have compromised muscle growth since there were no differences between the systems in this stage. However, it is possible that the level of hypertrophy occurring in ponds at this stage was related to the growing phase and not to the absence of low temperature. However, due to the discovery of other factors that may have affected muscle growth in the hapas, it is possible that low temperatures did not act alone. Matschak et al. (1998) observed a reduced number of white fibers with a decrease in oxygen tension at low temperatures in rainbow trout embryos (Oncorhynchus mykiss). Based on this, it is possible that the lower levels of hypertrophy in hapas in the present study may have been caused by the joint action of low DO levels and low temperatures rather than by the isolated action of each of these factors.

Additionally, the availability of natural food in earthen ponds, as evidenced by the turbidity data, may have promoted further fiber growth due to its high nutritional value. Ribeiro et al. (2011) found a greater accumulation of crude protein in tilapia muscle grown in earthen ponds compared with those reared in concrete tanks. Abou et al. (2013) observed that $O$. niloticus receiving the same diet had a higher average final weight in earthen pond cultivation when compared to concrete tank cultivation. As these characteristics relate to muscle growth, it is possible that the availability of natural food in earthen ponds in the present study influenced the higher incidence of hypertrophic growth.

Regarding the differences in fiber growth within varieties among the systems, growth was higher in GIFT individuals. The greater hypertrophy occurred in ponds possibly due to the greater capacity of this variety to take advantage of favorable conditions present in this system for its own development. This feature probably results from the genetic improvement program implemented in this variety since the initial focus of the GIFT project was to assist

Genetics and Molecular Research 16 (1): gmr16019407 
production in earthen ponds (Bentsen et al., 2012), which also provided convenient results for other cultivation systems. Santos (2009) found higher heritability for GIFT body weight when reared in better nutrition conditions and higher aeration levels. This might explain why this variety requires appropriate conditions to reach its full potential, which accounts for the lower growth when cultivated in hapas under the conditions of the present study.

\section{Influence of stage, system, and variety on myostatin expression}

Distinctions in gene expression in the growing phase may be related to the results obtained for muscle growth. Comparison of the two systems showed that the highest level of myostatin expression in GIFT individuals was found in those reared in ponds, and when the two varieties were compared within earthen ponds, the GIFT variety exhibited greater hypertrophic growth during the growing phase. In the fattening phase, there were no differences in muscle growth or gene expression between the two varieties, which confirm this relationship. Taken together, these results demonstrate there is a possible relationship between MSTN-1 expression and increased fiber diameter.

In line with this, de Santis et al. (2012), found a positive (but not significant) correlation between the expression of MSTN-1 and the levels of hypertrophy in Lates calcarifer. Thus, MSTN-1 may stimulate the differentiation and fusion of myosatellite cells. Confirming this hypothesis, Garikipati and Rodgers (2012a) observed increased expression of MSTN-1a and MSTN-1b paralogs in $O$. mykiss during differentiation of cultured myosatellite cells suggesting the importance of these paralogs in this process. However, this does not explain the absence of negative growth control for myostatin since Garikipati and Rodgers (2012b) observed that the activation of differentiation by myostatin in $O$. mykiss is a consequence of its ability to inhibit myosatellite proliferation. This demonstrates a possible MSTN-1 association in activating the differentiation of myogenic precursor cells when suppressing their proliferation.

As they are subject to differentiation, one pathway these cells can follow is the absorption by growing muscle fiber, enabling fiber growth (Johnston et al., 2011), which is the definition of hypertrophy. Thus, it is possible that the greater MSTN-1 expression in the GIFT variety in earthen ponds was responsible for the increase in fiber diameter, because promoting differentiation may result from the fusion of precursor cells to the fibers, which is demonstrated by the increased frequency in fibers with a diameter $>50 \mu \mathrm{m}$. This suggests a possible influence of this factor in promoting muscle growth in tilapia under the conditions of the earthen pond cultivation system of this study, at least in the growing phase. Since the current study did not investigate the relationship between hypertrophy levels and MSTN-1 gene expression, despite fiber percentages with big diameters increasing with expression, it can be stated that a co-relationship exists between these data. Further studies are required to confirm the co-relationship between these factors in Nile tilapia. The current analysis assessed MSTN-1 expression during the final phases of culture (growth and fattening). Great relevance must be given to in-depth research evaluating expression during the initial phases and its corelationship with muscle growth.

Conversely, another trend was observed in the hapas cultivation due to the limiting environmental conditions of the system. When comparing the varieties in the growing phase, individuals of the Supreme variety exhibited a higher expression of myostatin when compared to individuals of the GIFT variety. However, the same pattern was not observed in the fattening stage. It is possible that the Supreme variety responded more effectively to temperature

Genetics and Molecular Research 16 (1): gmr16019407 
limitations and DO $(>2 \mathrm{mg} / \mathrm{L})$ in hapas, which culminated in a greater level of myostatin expression under these conditions. Although there was no significant difference in muscle morphology between varieties in hapas in the growing stage, or between hapas and ponds for the Supreme variety in the same stage, there was a greater number of individuals with fibers $>50 \mu \mathrm{m}$ diameter in the Supreme variety, which reinforces the findings obtained in the myostatin expression analysis. Furthermore, the GIFT individuals in hapas had significantly fewer fibers with diameter $>50 \mu \mathrm{m}$ compared with those in ponds in the growing stage. It is possible that there was late differentiation of muscle fibers in GIFT tilapia under these conditions, which would explain the higher expression in the fattening stage of this variety in the hapas.

Taken together, these findings indicate that the conditions present in earthen pond cultivation were more effective at stimulating muscle growth due to the presence of more suitable environmental conditions. GIFT variety fish exhibited greater fiber diameter in some phases, which may be related to their greater developmental ability under these conditions. Gene expression was higher during the growing stage of GIFT fish in ponds, coinciding with a higher level of hypertrophy, which may demonstrate the relationship between MSTN-1 and the increased diameter of white muscle fibers. These data reveal the influence of environmental factors on the growth of white muscle fibers in different varieties, and show that differences are caused by the selection process to which the fish are subjected. Data also revealed that selection for characteristics of productive performance may have altered the mechanisms of muscular growth.

These results are highly relevant since the influence of environmental factors on the modulation of mechanisms involved in the growth of white muscles may be employed to improve the management of tilapia culture and in genetic improvement programs of the species.

\section{Conflicts of interest}

The authors declare no conflict of interest.

\section{ACKNOWLEDGMENTS}

Research supported by CNPq and Capes.

\section{REFERENCES}

Abou Y, Aina MP, Fiogbé ED and Micha J (2013). Growth and fatty acid composition of Nile tilapia Oreochromis niloticus L. fed Azolla-diets, in tanks and in earthen ponds: A comparative study. Nat. Sci 5: 77-83.

Acosta J, Carpio Y, Borroto I, González O, et al. (2005). Myostatin gene silenced by RNAi show a zebrafish giant phenotype. J. Biotechnol. 119: 324-331. http://dx.doi.org/10.1016/j.jbiotec.2005.04.023

Aguiar DH, Bock C, Padovani CR and Dal Pai-Silva M (2008). MyoD, myogenin and proliferating cell nuclear antigen expression in growing Nile tilapia (Oreochromis niloticus L.). Aquacult. Res. 39: 1673-1679.

Alami-Durante H, Médale F, Cluzeaud M and Kaushik SJ (2010a). Skeletal muscle growth dynamics and expression of related genes in white and red muscles of rainbow trout fed diets with graded levels of a mixture of plant protein sources as substitutes for fishmeal. Aquaculture 303: 50-58. http://dx.doi.org/10.1016/j.aquaculture.2010.03.012

Alami-Durante H, Wrutniak-Cabello C, Kaushik SJ and Médale F (2010b). Skeletal muscle cellularity and expression of myogenic regulatory factors and myosin heavy chains in rainbow trout (Oncorhynchus mykiss): effects of changes in dietary plant protein sources and amino acid profiles. Comp. Biochem. Physiol. A Mol. Integr. Physiol. 156: 561-568. 
http://dx.doi.org/10.1016/j.cbpa.2010.04.015

Bentsen HB, Gjerde B, Nguyen NH, Rye M, et al. (2012). Genetic improvement of farmed tilapias: Genetic parameters for body weight at harvest in Nile tilapia (Oreochromis niloticus) during five generations of testing in multiple environments. Aquaculture 338-341: 56-65. http://dx.doi.org/10.1016/j.aquaculture.2012.01.027

Carani FR, Aguiar DH, Almeida FLA, Gonçalves HS, et al. (2008). Morfologia e crescimento do músculo estriado esquelético no pirarucu Arapaima gigas Cuvier, 1817 (Teleostei, Arapaimidae). Acta Sci. Biol. Sci. 30: 205-211.

Chisada S, Okamoto H, Taniguchi Y, Kimori Y, et al. (2011). Myostatin-deficient medaka exhibit a double-muscling phenotype with hyperplasia and hypertrophy, which occur sequentially during post-hatch development. Dev. Biol. 359: 82-94. http://dx.doi.org/10.1016/j.ydbio.2011.08.027

Dal Pai-Silva M, Carvalho RF, Pellizzon CH and Dal Pai V (2003). Muscle growth in Nile tilapia (Oreochromis niloticus): histochemical, ultrastructural and morphometric study. Tissue Cell 35: 179-187. http://dx.doi.org/10.1016/S0040$\underline{8166(03) 00019-3}$

de Almeida FL, Carvalho RF, Pinhal D, Padovani CR, et al. (2008). Differential expression of myogenic regulatory factor MyoD in pacu skeletal muscle (Piaractus mesopotamicus Holmberg 1887: Serrasalminae, Characidae, Teleostei) during juvenile and adult growth phases. Micron 39: 1306-1311. http://dx.doi.org/10.1016/j.micron.2008.02.011

de Santis C, Gomes GB and Jerry DR (2012). Abundance of myostatin gene transcripts and their correlation with muscle hypertrophy during the development of barramundi, Lates calcarifer. Comp. Biochem. Physiol. B Biochem. Mol. Biol. 163: 101-107. http://dx.doi.org/10.1016/j.cbpb.2012.05.008

FAO - Food and Agriculture Organization of the United Nations (2014). FAO yearbook: Fishery and Aquaculture Statistics, 2012. FAO, Rome.

Garikipati DK and Rodgers BD (2012a). Myostatin stimulates myosatellite cell differentiation in a novel model system: evidence for gene subfunctionalization. Am. J. Physiol. Regul. Integr. Comp. Physiol. 302: R1059-R1066. http:// dx.doi.org/10.1152/ajpregu.00523.2011

Garikipati DK and Rodgers BD (2012b). Myostatin inhibits myosatellite cell proliferation and consequently activates differentiation: evidence for endocrine-regulated transcript processing. J. Endocrinol. 215: 177-187. http://dx.doi. org/10.1530/JOE-12-0260

Gutierrez de Paula T, de Almeida FL, Carani FR, Vechetti-Júnior IJ, et al. (2014). Rearing temperature induces changes in muscle growth and gene expression in juvenile pacu (Piaractus mesopotamicus). Comp. Biochem. Physiol. B Biochem. Mol. Biol. 169: 31-37. http://dx.doi.org/10.1016/j.cbpb.2013.12.004

Johnston IA (1999). Muscle development and growth: potential implications for flesh quality in fish. Aquaculture 177: 99-115. http://dx.doi.org/10.1016/S0044-8486(99)00072-1

Johnston IA, Bower NI and Macqueen DJ (2011). Growth and the regulation of myotomal muscle mass in teleost fish. $J$. Exp. Biol. 214: 1617-1628. http://dx.doi.org/10.1242/jeb.038620

Kubitza F (2011). Tilápia: tecnologia e planejamento na produção comercial. 2nd edn. F. Kubitza, Jundiaí.

Langley B, Thomas M, Bishop A, Sharma M, et al. (2002). Myostatin inhibits myoblast differentiation by down-regulating MyoD expression. J. Biol. Chem. 277: 49831-49840. http://dx.doi.org/10.1074/jbc.M204291200

Lee CY, Hu SY, Gong HY, Chen MHC, et al. (2009). Suppression of myostatin with vector-based RNA interference causes a double-muscle effect in transgenic zebrafish. Biochem. Biophys. Res. Commun. 387: 766-771. http://dx.doi. org/10.1016/j.bbrc.2009.07.110

Mareco EA (2012). Efeitos da temperatura na expressão de genes relacionados ao crescimento muscular em tilápias do Nilo (Oreochromis niloticus) linhagem GIFT. Master's thesis, Universidade Estadual Paulista, Botucatu.

Matschak TW, Hopcroft T, Mason PS, Crook AR, et al. (1998). Temperature and oxygen tension influence the development of muscle cellularity in embryonic rainbow trout. J. Fish Biol. 53: 581-590. http://dx.doi.org/10.1111/j.1095-8649.1998. $\underline{\text { tb01003.x }}$

Moro GV, Torati LS, Luiz DB and Matos FT (2013). Monitoramento e manejo da qualidade da água em pisciculturas. In: Piscicultura de água doce: Multiplicando conhecimentos (Rodrigues APO, Lima AF, Alves AL, Rosa DK, et al. eds.). 1st edn. Embrapa, Brasília, 141-169.

MPA - Ministério da Pesca e Aquicultura (2013). Boletim Estatístico da Pesca e Aquicultura 2011. MPA, Brasília.

Nebo C, Portella MC, Carani FR, de Almeida FL, et al. (2013). Short periods of fasting followed by refeeding change the expression of muscle growth-related genes in juvenile Nile tilapia (Oreochromis niloticus). Comp. Biochem. Physiol. B Biochem. Mol. Biol. 164: 268-274. http://dx.doi.org/10.1016/j.cbpb.2013.02.003

Periago MJ, Ayala MD, López-Albors O, Abdel I, et al. (2005). Muscle cellularity and flesh quality of wild and farmed sea bass, Dicentrarchus labrax L. Aquaculture 249: 175-188. http://dx.doi.org/10.1016/j.aquaculture.2005.02.047

Pfaffl MW (2001). A new mathematical model for relative quantification in real-time RT-PCR. Nucleic Acids Res. 29: e45. http://dx.doi.org/10.1093/nar/29.9.e45

Genetics and Molecular Research 16 (1): gmr16019407 
Rasmussen R (2001). Quantification on the lightcycler. In: Rapid cycle real time PCR: methods and applications (Meuer S, Witter C and Nakagawara K, eds.). Spring, Berlin, 21-34.

Ribeiro PAP, Rosa PV, Vieira JS, Gonçalves ACS, et al. (2011). Perfil lipídico e composição química de tilápias nilóticas em diferentes condições de cultivo. Rev. Bras. Saúde. Prod. Anim. 12: 199-208.

Rodriguez Rodriguez MDP (2014). Polimorfismos no gene do hormônio do crescimento associado a características de crescimento de tilápia do Nilo. Doctoral thesis, Universidade Estadual de Maringá, UEM, Maringá.

Salomão RAS (2014). Crescimento compensatório em linhagens de tilápia do Nilo (Oreochromis niloticus L.) cultivadas em ambiente resfriado: morfologia muscular e expressão de genes relacionados ao crescimento muscular. Master's thesis. Universidade Estadual Paulista, Jaboticabal.

Santos AI (2009). Interação genótipo-ambiente e estimativas de parâmetros genéticos em tilápias. Doctoral thesis. Universidade Estadual de Maringá, UEM, Maringá.

Seiliez I, Sabin N and Gabillard JC (2012). Myostatin inhibits proliferation but not differentiation of trout myoblasts. Mol. Cell. Endocrinol. 351: 220-226. http://dx.doi.org/10.1016/j.mce.2011.12.011

Stoiber W, Haslett JR, Wenk R, Steinbacher P, et al. (2002). Cellularity changes in developing red and white fish muscle at different temperatures: simulating natural environmental conditions for a temperate freshwater cyprinid. J. Exp. Biol. 205: 2349-2364.

Valente LMP, Rocha E, Gomes EFS, Silva MW, et al. (1999). Growth dynamics of white and red muscle fibres in fastand slow-growing strains of rainbow trout. J. Fish Biol. 55: 675-691. http://dx.doi.org/10.1111/j.1095-8649.1999. tb00710.x

Weber TE and Bosworth BG (2005). Effects of 28 day exposure to cold temperature or feed restriction on growth, body composition, and expression of genes related to muscle growth and metabolism in channel catfish. Aquaculture 246: 483-492. http://dx.doi.org/10.1016/j.aquaculture.2005.02.032

Xu C, Wu G, Zohar Y and Du SJ (2003). Analysis of myostatin gene structure, expression and function in zebrafish. J. Exp. Biol. 206: 4067-4079. http://dx.doi.org/10.1242/jeb.00635

Zhao Y, Wang J, Thammaratsuntorn J, Wu JW, et al. (2015). Comparative transcriptome analysis of Nile tilapia (Oreochromis niloticus) in response to alkalinity stress. Genet. Mol. Res. 14: 17916-17926. http://dx.doi. org/10.4238/2015.December.22.16

Genetics and Molecular Research 16 (1): gmr16019407 